\title{
Impact of adversity intelligence and work commitment on cyberloafing behavior
}

\author{
Tri Rahayuningsih ${ }^{*}{ }^{1}$, Ardian Adi Putra ${ }^{2}$ \\ ${ }^{12}$ Universitas Abdurrab Pekanbaru \\ ${ }^{*}$ Corresponding author, $\equiv$ e-mail: tri.rahayuningsih@univrab.ac.id
}

\begin{abstract}
This study aimed to determine the effect of intelligence adversity and work commitment to cyberloafing behavior of lecturer at the Asean Economic Community (MEA)'s era. So, this research beneficial to the development of theoretical science of industrial and organizational psychology about work behavior, as well as suggestions to keep the factors that make lecturer can avoid unproductive work habits that was cyberloafing, given the importance of the role of the faculty. This study used a quantitative method by spreading questionnaires to lecturers consisting of adversity intelligence scale, work commitment scale, and cyberloafing behavior scale that researchers collated by self, and analyzed statistically to discussed the cyberloafing behavior of lecturers. According to Lim (2002) cyberloafing an employee volunteer activities in the office, in using the internet access that has no correlation in the work. The result of this research showed that there is correlation between adversity intelligence and work commitment with cyberloafing behavior based on $p$ value $=0,042$ hence acceptable hypothesis, and contribution of adversity intelligence and work commitment equal to $19 \%$ to cyberloafing behavior. It is expected to be a suggestion for Higher Education to improve the quality of lecturer in facing MEA.
\end{abstract}

Keywords: cyberloafing behavior, adversity intelligence, work commitment

How to Cite: Rahayuningsih, T., Putra, A. A. (2017). Impact of adversity intelligence and work commitment on cyberloafing behavior. Couns-Edu: International Journal of Counseling and Education, 3(2): pp. 69-72. DOI: https://doi.org/10.23916/0020180311620

\section{Introduction}

The Internet is an abbreviation of the interconnection-networking, could be interpreted as an interconnected network. Internet services can also be used in various fields, such as education, social, banking, health, and work or business, so, many companies have also utilized internet facilities (Lim, 2002). Employee performance can be improved through various facilities provided by the internet in facilitating employee performance. While internet access has become commonplace, employee inclination to use the internet as an entertainment and non-work-related destination will also increase (Blanchard \& Henle, 2008). Internet access provided by the company during working hours take place, to explore sites that are not related to the job for personal gain, and to check (including receiving and sending) electronic message personally conducted voluntarily by employees called Cyberloafing (Lim , 2002).

Readiness for ASEAN Economic Community (MEA) should be undertaken by Universities. Therefore, Higher Education is responsible for producing competent scholars and can compete globally. It needs special attention from each lecturer as an educator to give a qualified graduate 
candidate (Sulistyoningrum, 2015). Many problems faced as a lecturer while job and holding concurrent positions, as well as the lack of motivation for continuous self-improvement, and lack of discipline in teaching. In fact, lecturers are required to continue the study, research, and follow training to increase their knowledge and technology (Angelina, 2015).Therefore, in facing the era of ASEAN Economic Community, lecturers need the ability to face all challenges of work and also have a high work commitment to produce work behavior being productivity. Work commitment is employee loyalty to organization through the acceptance of goals, organizational values, willingness to try to be a part of organization, and desire to survive in the organization (Finegan, 2000).

According to Stoltz (2000), a person with high adversity intelligence tends to assume the difficulties come from outside him and place his own role in a reasonable place. The individual will judge his role and learn from his behavior, so that he can be smarter, faster, better or more effective when faced with similar problems. Difficulties precisely make it an unyielding person, where they are optimistic people who view difficulty is temporary and can be overcome. Lecturers need this ability, especially faced of ASEAN Economic Community's era as state all work full of dynamics and their challenges to be faced lecturers working to meet the obligations of Tri Dharma's College.

Various efforts have been made in facilitating lecturers to be ready to face the era of ASEAN Economic Community. Research grants and community service programs, instructional grants, incentives for journal writing from government (Kemenristek Dikti), and support from universities to help lecturers improve the quality of scientific writing as lecture materials and various trainings or seminars that foster an academic atmosphere. The problem is, the work that becomes lecturer's routinity was often considered boring, so lecturers often neglected their obligations during working hours. From the researcher's observation, it was seen that some lecturers still do not utilize the information technology facilities for their competence development. Especially with the sophistication of technology in this globalization, there are still many who use internet facilities for personal pleasure at working hours, such as messaging, using social media, or for entertainment. Therefore, it takes a high work commitment so that lecturers do not wasted their time, especially in working hours to do something that is not related to his work as a lecturer.

In line with this, Cyberloafing behavior on lecturer could be an important topic to investigated. Cyberloafing behavior is behavior of someone who deliberately uses information technology and internet access that is personal in working hours that no have related with the work, even it should be completed in a timely manner and can harm the organization because it was impact on worker productivity (Lim, 2002; Blanchard \& Henle, 2008). Given the readiness of lecturer to faced the era of ASEAN Economic Community, lecturers need adversity intelligence and work commitment. This research hypothesized that there is the influence of adversity intelligence and work commitment towards cyberloafing behavior on lecturer at the ASEAN Economic Community. It was assumed that the higher adversity intelligence and the higher work commitment, so cyberloafing behavior have been lower. Likewise, the lower adversity intelligence and the lower work commitment impact to the higher cyberloafing behavior on lecturers.

\section{Method}

These research is a correlation study with cyberloafing behavior as $Y$ variables, adversity intelligence as X1 and work commitments as X2, so we could seen the relationship between adversity intelligence and work commitment with cyberloafing behavior and amount of influence adversity intelligence and work commitment towards cyberloafing behavior. This study took place in several Universities in Pekanbaru. Subjects in this study is active lecturer at universities in Pekanbaru. According to Arikunto (2006), the number of 100 subjects is considered to have met the ideal sampling. The sampling method that will be used was incidental sampling that was sampling technique based on coincidence, the researcher met with subject that can be used as sample (Sugiyono, 2013).

This study used quantitative methods of data collection through a questionnaire that consisted of adversity intelligence scale, work commitment scale, and cyberloafing behavior scale that researchers collated based behavioral indicators of aspects of each variable into multiple point-item statement as follows:

\begin{tabular}{ll}
\hline behavior cyberloafing & Browsing activity and e-mail (Lim, 2002) \\
\hline Adversity intelligence & control, origin and ownership, reach, and endurance (Stoltz, 2000) \\
Work commitment & Affective commitment, continoues, and normative (Meyer et al, 2002) \\
\hline
\end{tabular}




\section{Results and Discussions}

This research performed two statistical analyzes namely normality test and hypothesis test. Based on normality result indicated that data of cyberloafing variable, work commitment and adversity intelligence have Kolmogorov-Smirnov $\mathrm{Z}$ value greater than $0,05(\mathrm{p}>0,05)$. Thus it could be said that the results obtained from the distribution in the study showed a normal distribution.

Table 1. Normality Test

\begin{tabular}{cccc}
\hline & Cyberloafing & $\begin{array}{c}\text { Organization } \\
\text { Commitment }\end{array}$ & $\begin{array}{c}\text { Adversity } \\
\text { Intelligence }\end{array}$ \\
\hline Kolmogorov-Smirnov Z &, 482 &, 976 &, 596 \\
Asymp. Sig. (2-tailed) &, 974 &, 297 &, 870 \\
\hline
\end{tabular}

To test the hypothesis, researchers used multiple regression analysis with SPSS 20.0 for Windows. The result showed that $p=0.042$ it means $p<0.042$ thus, there was a significant relationship together between adversity intelligence and work commitment with cyberloafing behavior.

\begin{tabular}{|c|c|c|c|c|c|c|}
\hline \multicolumn{7}{|c|}{ Table 2. ANOVA ${ }^{b}$} \\
\hline Model & & Sum of Squares & $\mathrm{df}$ & Mean Square & $\mathrm{F}$ & Sig. \\
\hline \multirow[t]{3}{*}{1} & Regression & 808,790 & 2 & 404,395 & 3,524 &, $042^{\mathrm{a}}$ \\
\hline & Residual & 3442,725 & 30 & 114,758 & & \\
\hline & Total & 4251,515 & 32 & & & \\
\hline $\begin{array}{l}\text { a. Pred } \\
\text { b. Dep }\end{array}$ & $\begin{array}{l}\text { tors: (Consta } \\
\text { dent Variabl }\end{array}$ & $\begin{array}{l}\text { dversity, commitr } \\
\text { erloafing }\end{array}$ & & & & \\
\hline
\end{tabular}

From the regression test results obtained Rsquare coefficient of 0.19 which means that the adversity intelligence and work commitment together contributed to influenced cyberloafing behavior by $19 \%$.

\begin{tabular}{|c|c|c|c|c|}
\hline \multicolumn{5}{|c|}{ Table 3. Model Summary } \\
\hline Model & $\mathrm{R}$ & R Square & Adjusted R Square & $\begin{array}{l}\text { Std. Error of the } \\
\text { Estimate }\end{array}$ \\
\hline 1 &, $436^{a}$ & ,190 & ,136 & 10,712 \\
\hline
\end{tabular}

Cyberloafing is behavior of someone who knowingly used information technology and internet access that was private during working hours. It means has nothing to do with the work that should be resolved in a timely and potentially harmful to organizations or agencies, so it was impact on productivity of the worker. Changed in the current world of academic environment, among others, globalization and information technology is a reality that must be faced by lecturers in the era of MEA. A dedicated lecturer that has a high work commitment will prioritize the time for his duties and responsibilities. However, it also found a lecturer who has a negative attitude towards his profession. The duty of Tri Darma of Higher Education can be considered a burden if the lecturer does not have ability to face the challenges of work which is often referred to as adversity intelligence.

According to Ozler (2012), there are three factors that cause the emergence of cyberloafing behavior. The three factors are as follows: 1) Human behavior are several things from happening to the urges that come from the individual itself, as well as cyberloafing. There are several things from within the individual that belong to the individual factor (Perceptions and Attitudes: Employees who have a positive attitude toward computers have a tendency to use computers at work for personal gain. It also has a positive relationship with cyberloafing, Personal Trait: Selfcontrol is a personal trait that influences a person's cyberloafing activity, in which individuals with low self-control do more cyberloafing than individuals with high self-control, Internet Habits and Addictions: Habit is an activity that is done repeatedly so it becomes automatic. A person who has uncontrollable habits can become addicted); 2) Demographic Factors, Gender and age are demographic factors that contribute to cyberloafing. But to date, findings from different studies show contradictory results, so it cannot be specified what gender and age will have an effect on cyberloafing (Weatherbee, 2010); 3) Organizational Factors: Based on the researches that have been done by various researchers, got the factors related to the organization 
that certainly has an effect on cyberloafing on the employees. High job commitment, heavy sanctions, ambiguous managerial support, and high-demand job characteristics are factors considered to reduce the individual's inclination in cyberloafing; 4) Situational Factors: Weatherbee (2010) explains that employees who have access to Internet use in the workplace are more likely to be employees who do cyberloafing.

Resulted of previous studies (Aghaz \& Sheikh, 2016) stated that the behavior and activities of cyberloafing can be generated from job burnout, namely physically and mentally lackness. We need to design electronic control laws such as the internet and smartphones policy in the office, which is in line with the efforts to enhance the perception of organizational justice between employees, thereby increasing the level of employee discipline, one of which is shown by the attendance (Henle, Kohut, \& Booth, 2009). Other factors that could cause cyberloafing such as job characteristics, work attitudes, and management support in the used of Internet (Liberman, Seidman, McKenna, \& Buffardi, 2011), as well as demographic factors ie age, gender, and tenure (Baturay \& Toker, 2015 ).

\section{Conclusion}

There was effect of adversity intelligence and work commitment towards cyberloafing behavior of lecturers in the Asean Economic Community by 19\%, thus the hypothesized was accepted. Practical advice could be used for universities to reduced cyberloafing behavior of lecturer by improved adversity intelligence and work commitment of lecturers in faced AEC through regulating the use of internet and organizational design with good government.

\section{References}

Angelina, D. (2015). Dosen dituntut tingkatkan kualitas. Diakses dari http://nasional.sindonews.com/read/970738/162/dosen-dituntut-tingkatkan-kualitas-1425267604

Arikunto, S. (2006). Prosedur penelitian: Suatu pendekatan praktek. Jakarta: Rineka Cipta.

Aghaz, A., \& Sheikh, A. (2016). Cyberloafing and job burnout: An investigation in the knowledgeintensive sector. Computers in Human Behavior, 62, 51-60. https://doi.org/10.1016/j.chb.2016.03.069

Baturay, M. H., \& Toker, S. (2015). An investigation of the impact of demographics on cyberloafing from an educational setting angle. Computers in Human Behavior, 50, 358-366. https://doi.org/10.1016/j.chb.2015.03.081

Blanchard, A., \& Henle, C. (2008). Correlates of different forms of cyberloafing: The role or norms and external locus of control. Computers in Human Behavior, 24, 1067-1084.

Finegan, J.E. (2000). The impact of person and organizational values on organizational commitment. Journal of Occupational and Organizational Psychology, 73, 149- 169.

Henle, C. A., Kohut, G., \& Booth, R. (2009). Designing electronic use policies to enhance employee perceptions of fairness and to reduce cyberloafing: An empirical test of justice theory. Computers in Human Behavior, 25(4), 902-910. https://doi.org/10.1016/j.chb.2009.03.005

Liberman, B., Seidman, G., McKenna, K. Y. A., \& Buffardi, L. E. (2011). Employee job attitudes and organizational characteristics as predictors of cyberloafing. Computers in Human Behavior, 27(6), 21922199. https://doi.org/10.1016/j.chb.2011.06.015

Lim, V . K. G. (2002). The IT way of loafing on the job: Cyberloafing, neutralizing, and organizational justice. Journal of Organizational Behavior, 23, 675-694.

Meyer, J.P., Stanley, D.J., Herscovitch, L \& Topolnytsky, L (2002). Affective, Continuance, and Normative Commitment to the Organization: A Meta-analysis of Antecedents, Correlates, and Consequences. Journal of Vocational Behavior, 61, 20-52.

Ozler, D. E., \& Polat, G. (2012). Cyberloafing phenomenon in organizations:Determinants and impact. Internasional Journal of e-Bussiness and e-Government Studies, 4(2), 1-15

Stoltz, P. G. (2000). Adversity quotient, mengubah hambatan menjadi peluang. Penerjemah: T. Hermaya. Jakarta: Grasindo.

Sulistyoningrum, Y. (2015). Dosen juga dituntut siap hadapi MEA. Diakses dari http://kabar24.bisnis.com/read/20150629/255/448339/dosen-juga-dituntut-siap-hadapi-mea

Weatherbee, T. G. (2010). Counterproductive use of technology at work:Information and communications technologies and cyberdeviancy. Human Resource Management Review, 12, 3-21. 